\title{
Working Together: Towards an Inclusive Federalism?
}

\section{Campbell Sharman}

I

was probably asked about the title of my paper, and may well have agreed to the present one, but it looks now like a mild contradiction in terms (the question mark is my subsequent addition). It reminds me of Tony Blair's comment in his address to the recent British Labour Party Conference that he was committed to 'compassion with a hard edge'. This is not in the same class as those great oxymorons like a 'deafening silence' or 'military intelligence', but it has a certain appeal. 'Working Together: Towards an Inclusive Federalism?' could be in the same category. The whole point of federalism is to have several governments that distrust each other in a way that produces enough tension and competition to make the system work properly (see Dye, 1990:ch. 1). Federalism is about the constructive use of distrust, not about working together in harmony. Governments that work together inclusively are the worst kind: they are (with apologies to Adam Smith) almost certainly planning some conspiracy against the public or some contrivance to raise taxes.

The idea of designing a system of government in which ambition fights ambition is a very old one (Ostrom, 1987). It underpins the idea of constitutionalism on which our system of liberal democracy is based. The separation of powers between the legislature, the executive and the judiciary is designed to disperse power between various agencies of government so that they can act as a check on each other and prevent the concentration of power that leads to the arbitrary and dictatorial use of government authority. Only by setting up institutions that are designed to oppose each other can openness, accountability and responsiveness to the public be guaranteed.

Federalism takes this process an additional step by dividing power between a central government and State governments that represent regional communities. In this way, the States can represent the interests of their political communities and carry out policies that reflect the preferences of regional majorities whether or not these policies would be supported by a national majority. Central governments are responsible only for those matters where, as the economists would say, externalities

Campbell Sharman is Associate Professor of Political Science at the University of Western Australia. This article is an edited and revised version of a keynote address originally prepared for 'Reshaping Government for the New Millennium', Annual State Conference of the Institute of Public Administration (WA Division), Esplanade Hotel, Fremantle, 14-15 October, 1997. 
abound: that is, only those matters which necessarily affect the interests of residents across the federation and cannot be dealt with through joint action by State governments (Ostrom, 1974).

Such a system of government has many advantages. It not only provides a governmental structure that reflects regional preferences more efficiently than a unitary government, but it sets up constitutionally entrenched governmental units that can monitor the activities of other governments. There is no more effective way of checking the action of one government than by the counter-action of another government. Given the ineffectiveness of some of our parliamentary institutions, public dispute between the various spheres of government may sometimes be the only way in which the openness and accountability of government actions can be ensured.

If federalism is such a wonderful system of government, why are there frequent complaints about it and repeated suggestions to alter the way it operates? Is there something wrong with the design of the Australian federal system? I would be the first to concede that the answer to these questions depends very much on one's point of view. Much of the problem with debates over the Australian federal system, at least until recently, was that they were like the sound of one hand clapping: there was a great deal of criticism but little support (Galligan, 1995:ch. 2; Sharman, 1992). There has been a long tradition of complaints about federalism precisely because it divides power and checks governments. This attitude is derived from the same majoritarian tradition that criticises the Senate, constitutional referendums, and judicial review of the Commonwealth Constitution because these institutions prevent the government of the day being able to do exactly what it likes in the name of a popular mandate. This view has long characterised the attitude to federalism held by the Australian Labor Party, or at least that section of the party in Canberra, and it is shared in varying degrees by both Labor and Liberal parties when they hold national office. It is the occupational hazard of being in government to believe that Canberra knows best, particularly the executive branch. Such a view leads to hostility towards any institution that checks the partisan ambitions of the government of the day - which is precisely why such limiting institutions and an entrenched constitution exist.

I should also mention the regional bias against federalism found in New South Wales. Recently in Sydney I was reminded that the most parochial newspaper in Australia is the Sydney Morning Herald. On occasion it will concede that Melbourne exists but generally the paper gives the impression that no Australian news occurs outside New South Wales, which, of course, includes Canberra. This reflects the view of most residents of the State that there is no need for federalism because New South Wales is Australia.

\section{The Fallacies of Centralism}

This aside, I am concerned not with criticisms of federalism, but with criticisms that the federal system is not working as well as it should. So, with the exception of a design fault in the Commonwealth Constitution to which I shall refer later, and 
which has proved to have major consequences for the operation of the federal system, the answer to the question of whether there is anything wrong with the design of the Australian federal structure is, by and large, 'no'. This has been the opinion of the Australian electorate which has rejected all but eight of the 42 constitutional amendments submitted to the people since federation, and none of the successful amendments has affected the basic structure of the federal system. The compromise worked out to establish the federal union of 1901 has all the features that permit the benefits of a federal system of government to be fully exploited. The problem has been that in practice, and with more than a little help from the High Court, the creative tension inherent in the federal system has been steadily eroded by the increasing involvement of the central government in areas outside its intended jurisdiction. This has had two very bad effects.

The first is that it increasingly denies the opportunities for the States as political communities to find solutions to their own distinctive problems. Even though the Australian States and Territories vary less in their socio-economic composition than the components of most federations, the States have substantially different needs and face markedly different problems. The economies of South Australia and Victoria, disproportionately dependent as they are on tariff-protected industry and suffering a decline in relative population size, differ substantially from the resource and technology driven economies of Queensland and Western Australia. Besides, the much commented-upon similarity of State populations is changing rapidly with immigration and economic growth so that the States are diverging in their social and economic profiles.

A related aspect of the bad effect of greater uniformity is that it prevents the application of a range of solutions to problems that are common to all States. In some respects, it is the denial of experimentation in the solution of similar problems that is most worrying. Over recent years that has been constant reference, usually on the part of the Commonwealth government, to the need for national solutions and uniform laws to deal with a wide range of problems. This has ranged from demands for the same blood-alcohol limits for drink-driving laws, to pressure for a uniform national school curriculum. While there may be some cases where a single set of rules is justifiable, the unstated assumption is that national uniformity is intrinsically desirable. The fact that a problem is common to all residents of Australia has been taken as evidence that a uniform solution is required. We are all Australians, goes the call from the Commonwealth, so the same rules should apply to everyone.

This is as illogical as it is self-serving. It is true that the issue of providing the most appropriate health and education services, transport and water infrastructure, zoning and environmental laws are common to all Australians throughout the federation, but it is not true that there needs to be a single solution. Different communities have different preferences and the whole point of living in a free society is that we can devise institutional arrangements that permit diversity to flourish. Only in this way can we exercise choice effectively and feel that we are participating in shaping the decisions that affect our lives. If one community wants to spend more 
on public health and less on education than another, why should this be prevented? If community standards vary, why should not communities vary in the rules governing criminal behaviour? Another way of framing the issue is to ask why uniformity should be preferred to diversity if communities find equally satisfactory but different solutions to the same problem.

A related fallacy is that these complicated issues have one single best solution. There is no one best way to provide education or health care. The are many solutions reflecting differing tradeoffs between the many considerations involved. It is not only undemocratic to prevent communities from finding their own solutions to these problems, it is also inefficient. To prevent diverse solutions is like preventing car manufacturers from producing different models, or drug companies from trying new drugs, or publishers from publishing different books. It is an arrogant denial of the need for experimentation to cope with a constantly changing world and to keep government services responsive to the communities they serve.

But, some will say, what about national standards? Isn't it important that there is general agreement on policies which have large spillover effects beyond the limits of any one State? Yes, but if uniform rules are to be preferred to deal with a particular problem, the way in which uniformity is achieved is itself important (note Pendal, 1996). Uniformity can be imposed or be the consequence of a negotiated solution. Unfortunately, the Commonwealth is often in the position to force uniform solutions on the States, usually through financial pressure but sometimes through the extensive ambit given to its constitutional powers by the High Court. However derived, the ability to impose a uniform solution is guaranteed to produce a less satisfactory solution than a negotiated one, and on most occasions no solution is preferable to an imposed solution. Much of the justification for unilateral Commonwealth action is driven by the rhetorical ploy of arguing that any solution is better than none, even though those who have the responsibility of administering the solution are happy to live with the existing problem. The Commonwealth, for example, argued that there was a need for uniform blood-alcohol limits for drinkdriving laws but, when pressed on the conflicting evidence about the effect of differing blood alcohol limits, could only point to the lack of uniformity as the problem that was to be overcome.

To begin with, a negotiated solution will involve compromise and will secure wider agreement than an imposed solution which only has to please the dominant party. Second, the framing of policy is a highly complex task and likely to generate unintended consequences and costs. Negotiation makes the process of policy formation less error prone and reduces risk. Third, by involving a wider range of interests in the final decision, negotiation ensures that decisions are given greater authority and legitimacy. These attributes are axiomatic, but they are well documented in the effect that the Senate has had in vastly improving the operation of the legislative process in the Commonwealth Parliament through the Senate's ability to force compromise. Of course, negotiation may slow down the process of framing policy and may offend the partisan or bureaucratic certainties of the instigating agency. But these costs to the would-be dominator are benefits to everyone else. 
There is an added reason why solutions imposed by the Commonwealth on the states are particularly unsatisfactory. The States are the dominant agency in the provision of services and the day-to-day administration of the machinery of government. The Commonwealth may have the money, but the States have the practical knowledge and administrative experience in delivering the service. This means that Commonwealth-State transactions that are dominated by the Commonwealth, and particularly those that are driven by conditional grants, are likely to take the form of unequal bargains in which the States feel they are constrained to take note of programme specifications produced by a Commonwealth agency that has little practical knowledge of the problems faced by the state agency. This is quite apart from the fact that each agency has political priorities that are likely to diverge. Such a situation provides strong incentives for the State agency to try to circumvent grant conditions, and equally strong incentives for the Commonwealth agency to impose ever stricter conditions, performance indicators and auditing requirements on grants.

This spiral of cheating and checking generates the kind of bureaucratic nonsense that is the bread and butter of intergovernmental relations. It is the reason why trying to implement policy through conditional grants guarantees that real political problems are likely to be ignored in favour of the meta-politics of bureaucratic competition and rent-seeking. I am not arguing that all Commonwealth-State agreements are doomed to be ineffective and wasteful, just those where the negotiations are one sided in favour of the Commonwealth. Unfortunately, the bulk of intergovernmental relations in Australia is driven by the financial dominance of the Commonwealth and this is precisely the circumstance that produces the most dysfunctional outcomes.

\section{Restoring Genuine Intergovernmental Competition}

So much for the wickedness of attempting to impose uniform solutions on problems which require diverse answers or negotiated settlements. But this is only one of the bad effects of the involvement of the Commonwealth in areas outside its administrative competence. The other bad effect is the reduction of competition in the federal system.

This sounds like a paradox because, if the Commonwealth is involved in areas which are the concerns of the States, there ought to be more competition, not less. It has often been noted that the concurrent nature of most Commonwealth powers, and the use of Commonwealth financial muscle to influence policies in areas of state responsibility, has meant increased competition and increased responsiveness in the system as a whole because of the competition between State and Commonwealth government and the greater number of access points for interest groups. The overlap and duplication of government activity between State and Commonwealth agencies may create some waste, but the overall effect is to add, as a colleague of mine put it, 'extra vitamins' to the policy process (Painter, 1988). This is a view I used to hold myself until I looked at the nature of the competition that was being created, or, rather, not created. 
Competition implies the ability to compete on a reasonably equal footing in a context where similar rules apply to the competing parties. With a few exceptions, this is not the nature of Commonwealth-State competition in areas where both governments are involved in framing policy. There are two reasons for this. The first is that the High Court has interpreted Section 109 of the Commonwealth Constitution in a way which strongly favours the Commonwealth. This section provides that a valid Commonwealth law overrides a State law to the extent of the inconsistency, and the High Court has held that almost any Commonwealth law in a given field overrides any State law in the same area even if it is possible to obey both laws, or if the State law deals with matters beyond the concern of the Commonwealth law. This has had the effect of giving the Commonwealth a very substantial advantage in any policy area in which it has jurisdiction, and has discredited the notion of concurrency.

The second and much more important reason is that the Commonwealth usually gains involvement in a policy area by offering funds to the States in return for political influence. As the States are already dependent on the Commonwealth for more than half their funds, and have become accustomed to assuming that they should never refuse any money offered by the Commonwealth, the nature of the negotiations is fairly one-sided. This is not competition but exploiting market dominance. The States are able to fiddle the details of most intergovernmental arrangements to suit State priorities, but this is hardly a ringing endorsement of increased competition in the federal system. At best it is cooperation under mild duress and at worst coercion modified by State ability to undermine the agreement by administrative deception.

There are some occasions where effective competition occurs between the States and the Commonwealth, but the prerequisite is that money is not the most important issue on the table. The recent negotiations over gun laws. for example, are a case in point. There was real competition in the sense that each State government had complete control over gun laws within its territory, and the Commonwealth had control over the importation of guns. The result was genuine compromise because no government could be coerced by another within the area of its jurisdiction. This is another paradox: the basis for effective competition, in the sense of the potential for the maintenance of different policy solutions to the same problem, is the most effective basis for compromise and the achievement of genuine cooperation.

But there is a more serious aspect of the loss of competition that follows from increasing Commonwealth intrusion into State administrative concerns. This is the reduction in the ability of States to compete in the provision of services where diversity can be of national benefit. One of the best examples of this is the administration of university education, an area clearly outside the Commonwealth's original jurisdiction. Since 1974 the Commonwealth has bought effective control of university education from the States by relieving them of the need to pay for universities. While universities are still State institutions governed by State laws, the Com- 
monwealth has secured, through a range of financial measures, close to monopoly control of the whole tertiary sector.

This dominance by a single government funding source has had a seriously debilitating effect on university education in this country. Quite apart from the question of the level of funding, Commonwealth control has killed much of the experimentation and diversity that is the life blood of a university system and that is required if the university sector is to serve the national interest in both teaching and research. As the West Report has put it, the Commonwealth regime has provided 'greater incentives to be the same rather than different' (HEFPRC, 1997:19). University administrators and academics spend too much of their time conforming with performance indicators, enrolment profiles and similar regulations that have more in common with the former communist regimes in Fastern Europe than with a free society. The idea that universities should be enterprises that make their own decisions and take responsibility for the level and variety of their fees, for the number of students they enrol and the courses they teach, seems not to have dawned on the Commonwealth government, even though it is the kind of solution that the Commonwealth has favoured for most other areas of government enterprise. Eight autonomous State and Territory university systems would not guarantee that no mistakes would be made, but it would mean that there would be much more diversity and resilience in the university sector, and that disasters were quarantined rather than affecting the whole system. Such a dispersed system of public universities is one of the reasons why the Canadian university system is much superior to ours.

\section{Prospects for Reform}

So much for the diagnosis. Our federal system is not working properly because of a loss of diversity in the system, a diversity that enhances creative competition and makes for greater responsiveness to citizen preferences, greater efficiency, and greater resilience in coping with national problems.

How can this situation be remedied? The answer is, with difficulty. The problem is that all the incentives are pointing the wrong way. The Commonwealth has no reason to reduce its involvement in any policy area in which it finds political gain, and the States are apprehensive about any changes that would force them to take more responsibility for raising taxes. For a while in the early 1990s, Prime Minister Hawke and a series of special premiers conferences gave the impression that some progress would be made. The States were to regain greater autonomy in some policy areas, while the Commonwealth would pick up more control in others. But the key element was greater financial autonomy for the States, and it was this proposal which attracted the ire of Mr Paul Keating. After Mr Keating's successful leadership challenge, the proposal sank without trace.

In the short term, the only real remedy is a financial one. Currently, the States raise less than half the revenue they spend, the remaining funds being transferred from the Commonwealth. The States need to be able to say 'no' to any Commonwealth involvement driven by financial inducement, and they can only do this if they can feel secure about the source of their funding. This security requires the States 
to have direct access to the major fields of taxation revenue from which they are presently excluded: consumption taxes and income tax. The High Court, through its idiosyncratic interpretation of Section 90 of the Commonwealth Constitution, has precluded states from raising taxes in the nature of retail sales taxes on goods, so State consumption taxes are not the answer. The States are currently discussing a number of proposals relating to Commonwealth-State finance, one of which is a Commonwealth-levied consumption tax, a fixed share of which is guaranteed to the States. But this cannot create long-term independence, partly because the States cannot control the levying of the tax and partly because such agreements can be revoked at the convenience of the Commonwealth.

If the States resumed access to personal income tax from which they have been, in practice, precluded since 1942 (Sharman, 1993), this would create a very different picture. If the whole field of personal income tax were taken over by the States, as was considered in the 1920s, there would be little need for any Commonwealth transfers. This would create competition with a vengeance, even if the income tax schedule and the rate of tax levied by the States were identical. It would mean not only vastly greater policy discretion for the States but also the end of all those Commonwealth departments such as health and education whose existence is dependent on monitoring Commonwealth transfers to the States. There would be no more premiers' conferences on finance as we know them because the States and Territories would be largely self-sufficient in revenue. There would still be discussions about borrowing, and additional negotiations about equalisation payments to the poorer States and Territories, but the main feature would be deep and meaningful discussions about the state of the economy and what State, Territory and Commonwealth governments could do jointly to regulate it.

Such a change would create a federal system with all the dynamics required for a highly responsive and effective political system but there are many reasons why such wholesale change, however desirable, is unlikely. The first is that the Commonwealth would be the big loser in both power and prestige. Another set of losers would be all those interest groups that depend on Commonwealth patronage in areas of State responsibility. This is now a very large and influential set of lobbyists. Even the big winners under such a system, the States, would be extremely apprehensive about such a revolutionary change. Not only would it require much greater State administrative responsibility for the framing of policy, but it would require a willingness to accept political responsibility for all aspects of State expenditure. While this would be wholly beneficial for State citizen voters, it would require a major change in mind-set for most State governments. They may complain about Commonwealth interference, but the thought of being completely responsible for health and education policy, for example, and for the raising of the tax to pay for these services, is likely to make them turn pale.

But the Canadians have shown that a half-way house is quite possible. Both spheres of government in Canada are involved in raising personal income tax on the same schedule, with minor variations in the rate of tax. Transfers to the Provinces remain in those areas of key concern to the central government, but the Provinces 
retain considerably more financial independence than the Australian States. I hope the premiers will support a similar scheme in the current round of discussions on federal finance, but I fear that Commonwealth intransigence and State faintheartedness will defeat such a reform. The States are still suffering from the view, mistaken in my opinion, that if a State opposition party mentions the words 'double taxation', any government that supports a State income tax will be defeated by the kind of huge swing that New South Wales premier Neville Wran gained using this slogan in the late 1970 s. As Sir Humphrey would say, a courageous decision is required.

\section{State-Initiated Constitutional Amendment}

Of course, we could try for a long-term solution to the problem. This brings us back to the design fault in the Commonwealth Constitution. At the moment, the only way that changes can be made to the formal structure of the Constitution is through changes initiated by the Commonwealth Parliament and accepted by the Commonwealth government before being put to the people at a constitutional referendum. This initiation procedure denies to the States the opportunity of proposing alterations to the Constitution. This is a serious omission because it denies voters the opportunity to express on opinion on proposals for constitutional amendment which might limit Commonwealth power, something the Commonwealth government is never likely to submit to the voters. My preference would be for an additional initiation process for constitutional change which could be set in train by a proposal for constitutional amendment being passed as a resolution by a majority of State legislatures. Such a proposal would then be required to be submitted to the people at a referendum and, if it gained the necessary majorities, would amend the Constitution.

Such a procedure would, at the very least, enable the electorate to pass judgment on the changes that have been made to the federal system by stealth. All these changes, whether deriving from judicial interpretation or from financial pressure, have worked in the direction of reducing State autonomy and increasing the ambit of a centrally initiated uniformity. A State-initiated constitutional amendment process could act as a vital corrective to the drift away from the diversity that underpins a successful federal system - and the betting is that such a procedure would greatly increase the success rate of constitutional amendments because the proposals would be the result of a process of intergovernmental compromise rather than the preferences of the Commonwealth cabinet.

But what about the title of this paper? How can I conclude without reinterpreting it so that it corresponds with what I have been talking about? The solution is to say that working together can take place effectively only if we know we can choose to work separately. We must be free not to work together, otherwise joint action is a form of slavery. The potential for serious conflict is the best argument for fruitful cooperation. The whole point of this paper is that the autonomy of the various political communities that comprise the federation is a vital prerequisite for the responsiveness and efficiency of the governmental system as a whole. 
As for an inclusive federalism, perhaps that is best left as a contradiction in terms or, as Sam Goldwyn said, '[ladies] and gentlemen, include me out'.

\section{References}

Commonwealth, Higher Education Financing and Policy Review Committee (HEFPRC) (1997), Learning for Life: A Policy Discussion Paper (the West Report), AGPS, Canberra.

Dye, T. (1990), American Federalism: Competition Among Govermments, Lexington Books, Lexington, Mass.

Galligan, B. (1995), A Federal Republic: Australia's Constitutional System of Government, Cambridge University Press, Melbourne.

Ostrom, V. (1973), 'Can Federalism Make a Difference?', Publius: The Journal of Federalism 3(2): 197-237.

- (1987), The Political Theory of a Compound Republic: Designing the American Experiment, University of Nebraska Press, Lincoln.

Painter, M. (1988), 'Australian Federalism and the Policy Process: Politics with Extra Vitamins', Politics 23(2): 57-66.

Pendal, P. (1990), Uniform Law in Australia: An Alternative Approach, Institute of Public Affairs, Melbourne (Federalism Project Issues Paper No. 6).

Sharman, C. (1992), 'Ideas and Change in the Australian Federal System', Australian Journal of Political Science 27 (Special Issue: Australian Federalism: Rethinking and Restructuring): 7-18

_ (1993), 'Changing Federal Finance: The Politics of the Reintroduction of State Income Taxes', pp. 221-37 in D. Collins (ed.), Vertical Fiscal Imbalance and the Allocation of Taxing Powers, Australian Tax Research Foundation, Sydney (Conference Series No. 13). 